\title{
Humane Religious from the Slope of Muria: A Pro- Existence Relationship Between Islam and Christianity in Tempur and Giling Villages
}

\author{
Kamilia Hamidah ${ }^{1}$, Danang Kristiawan ${ }^{2}$ and Abdullah $^{3}$ \\ \{kamiliahamidah@ipmafa.ac.id ${ }^{1}$, danangkristiawan7683@gmail.com² ${ }^{2}$ dullah.zubaidi@gmail.com $\left.{ }^{3}\right\}$ \\ IPMAFA Pati, Central Java, Indonesiaㄹ, STAKWW Pati, Central Java, Indonesia ${ }^{2}$, IAIN Kudus, \\ Central Java, Indonesia ${ }^{3}$
}

\begin{abstract}
Various incidents of religious intolerance occurred in Indonesia have contributed in damaging Indonesia's image as a tolerant nation. Narratives about the experience of living together as tolerant society needs to be explored. This paper will portray the practice of inter-religious tolerance that enlightens each other in two villages on the slopes of Muria, namely Tempur Village in Jepara Regency and Giling Village in Pati Regency, observe how theology and culture lived by the community play a role in shaping the construction pro-existence religious life. The study was carried out using a qualitative approach based on observation and interviews. The findings revealed how the people in the two villages exercise pro-existence tolerance, recognizes the existence of others, and brings others to life. This attitude is based on lived theology and local values, which further produce a humane religious attitude and also a means of transferring proexistence values to the next generation.
\end{abstract}

Keywords: Tolerance; Pro-existence; Islam-Christianity Relation; Humane Religion

\section{Introduction}

In the context of religious plurality in Indonesia, the problem of intolerance among religious believers continues to exist in several places. The SETARA Institute stated in a press release there was an increase in the freedom of religions and belief violations ahead of the year of Joko Widodo - Ma'ruf Amin's administration, namely the increasing expression of intolerance and discrimination aimed at minority groups. [1] Media presentations that highlight the rise in cases of intolerance in Indonesia have indirectly shaped the general public's perception of an increasingly intolerant Indonesian society. This has an indirect social effect on society in cognitive, affective, and behavioral aspects, because the effects of social conflicts in other areas frequently trigger / inspire conflicts in distant areas. From the perspective of Muslims, the country's majority group, various cases of intolerance have exacerbated the loss of the so-called smiling face of Indonesian Islam, which has increased since the reform era [2].

The rise in various forms of intolerance in society raises critical questions about various discourses on practice tolerance that frequently appear in the public sphere. Tolerance is frequently the discourse among elite groups, whether political or religious, but it turns out that it is not deeply rooted in religious praxis. Tolerance becomes cheap tolerance there, i.e., tolerance on the surface, which is ultimately fragile when dealing with issues involving 
interfaith identities. Whereas what is required is tolerance that recognizes each other, creates space, and living together (pro-existence). As a matter of fact, tolerance basically a costly tolerance, because it requires a willingness to accept different religious groups authentically and recognize equality as a value in and of itself, regardless of the power relations that exist in society [3] [4]. There is a negotiation between one religious group's identity in order to prevent dominating another and a willingness to share space with others in solidarity, which forms a tolerant and mutually reinvigorating plural community.

In reality, the study on intolerance is getting more attention than the study on the practice of tolerance that has been living in interfaith grassroot community. This study will look at the practice of religious relationships that illustrate this costly tolerance in the life of the community that living together (pro-existence) in two villages in the Pantura area around mount of Muria, namely the village of Giling in Pati Regency and the village of Tempur in Jepara Regency. The two villages are plural villages, with communities made up of Muslims, Christians, and Buddhists. The Pati Regency Government designated Giling Village as a Village of Religious Harmony Awareness Award in 2019. Meanwhile, Tempur village is known as a grass-roots tolerant village $[5,6]$.

This study will focus on the role of religion in fostering a mutually beneficial attitude (pro-existence) between the two villages. As a result, the focus of the article will be on the (theological) values that have played a role in shaping the tolerant attitude of the two religious' groups in dialectic culture, particularly in the negotiation process between their own religious identity and solidarity with other religions as members of the same society. Theological and cultural values to be addressed are theological values lived by the community (empirical theology), which are revealed in the narratives, experiences, and meanings of relation symbols in people's daily lives.

The purpose of this study is to describe the forms of pro-existence tolerance practiced by the people of Tempur and Giling Villages, to analyze the motivation or theological foundations that play a role in tolerant living practices through the interpretation of statements, symbols, and life practices, and to analyze the cultural context, which becomes a religious locus that can influence the style and practice of living. Furthermore, conclusions will be drawn from what was observed in the two villages to construct the study results conclusion.

\section{Literature Review}

In the context of religious plurality, interactions between religious communities become unavoidable. Negotiations will take place in a meeting among religious believers between a particular religious identity and together with other religions. Every religion required to be able to share space with others who have the same right to live. This is where tolerance takes place, so that diversity in a society does not exclude one another, but rather allows people to live together in harmony. But the question is, what kind of tolerance is practiced? Tolerance is understood in a variety of ways.

To begin with, there is tolerance as coexistence, which is tolerance understood as living together by giving each other space to live according to their rights. Tolerance in a liberal perspective prioritizes the rights and freedoms inherent in each individual and group to live and express themselves as they are. Everyone and groups have the same rights and cannot intervene with one another. Second, there can be tolerance as recognition, which is tolerance that not only Use the "Insert Citation" button to add citations to this document. 
Shares space with others and allows others to exist, but also recognizes one's rights as a member of society [7]. Recognition can take the form of recognition between different groups as well as political recognition from the state. [8]. Third, tolerances are pro-existence, that is, tolerance in which each group not only gives each other space or acknowledges each other, but also recognizes that their existence is to bring one another to life for the sake of a common life [9]. There is an awareness in pro-existence that every religious community as an interdependent entity with one another and that their lives are determined by this interdependence. This pro-existence attitude can be applied both in the external realm of religions (the context of life) and in the realm of religions themselves. Pro-existence in the context of religious life in the sense that interfaith involvement is intended to build a common life in society, either in dealing with common problems or in constructing a better place to live together. In the realm of interreligious relations, pro-existence occurs when one religious group and another religious group mutually depend on one another.

Several studies on the coexistence of religions, particularly between Muslims and Christians, have been conducted in the Muria region. According to these studies, several factors, including economic and kinship factors [10], the role of religious figures and cultural traditions [11], communication strategies [12], and a strong social identity, play significant role in forming a tolerant society on the slopes of Muria [13]. The majority of these studies concentrate on the role of external religious factors in the creation of tolerant social interactions. This is relevant because, after all, religion cannot be separated from the sociocultural factors that influence religious believers' interactions. However, this does not mean that the internal factors of religion, namely theological values of religion [14], are ignored, as these also shape the behavior of religious communities and the culture of society. As a result, there are always dialectics and theological (internal) aspects of religion that shape and influence the socio-cultural (external) aspects.

Religious values in society are not always expressed in strict and formal theological formulations. In fact, these values can be seen in how people live their lives on a daily basis. This is referred to as "lived religion" [15] or "everyday religion" [16]. Religion that is practiced in daily life is referred to as lived religion. Religion is viewed as a living religion that is contained in cultural works, giving attention to both institutions and individuals (individuals), visible texts and rituals, practice and theology, real things and ideas, all of which serve as media in representing the world that is understood and believed [17].

Seeing lived religion entails engaging in hermeneutic processes and empirical analysis of religious and spiritual practices expressed in society, rather than official doctrines and religious worship. As a result, religion is viewed as something fluid that manifests itself through action (praxis), experience, desire, thought, imagination, and other forms of power. This is not to say that religion is viewed solely as a subjective and individual experience. True, subjective experiences are highly valued, but these subjective experiences will also be implied in societal communal traditions. As a result, lived religion will always involve both micro (individual) and macro (socio-cultural) aspects in concrete and practical situations.

Theological values that underpin lived religion can also be viewed as lived theology or empirical theology. This means that theology is not recorded in systematic formulations, but rather in attitudes, experiences, personal reflections, or certain symbols that are familiar in daily life activities. This research will look at the practice of relations between Muslims and Christians in the villages of Tempur and Giling as a life dialogue that results in pro-existence tolerance through religious and cultural appreciation that intertwine in everyday life. 


\section{Method}

This research is a qualitative study using a descriptive-empirical method. The information was gathered through interviews with seven people from each village, with consideration given to their roles, gender, age, and religious background. Religious leaders from all religions, village head, community leaders, youth, women, and the general public are among the seven informants. Aside from interviews, research was conducted on supporting documents relevant to the purpose of this study. In the research report, all data will be collected, interpreted, and presented.

\section{Result and Discussion}

\section{1. Interfaith Pro-Existence in Tempur Village, Jepara and Giling Village, Pati}

\section{Overview of Pro-Existence Relationship in Tempur Village}

The highest village in the Muria mountains is Tempur Village. Because of its natural beauty, it has been designated as a tourist village since 2012. Furthermore, Tempur village is well-known for producing high-quality Muria mountain coffee. Tempur Village has a total population of 3,522 people, with a Muslim population of 3,481 people, a Christian population of 38 people, and a Buddhist population of three people [18]. The majority (almost entirely) of Muslims in Tempur are affiliated from Nahdhatul Ulama (NU). While all Christians are members of the GITJ (Evangelical Church in Tanah Jawa), a Mennonite church with a Javanese culture.

Despite the fact that the number of Muslims outnumbers Christians, the existence of Christians is still recognized, given space, and even revived. This occurred, for example, in the case of village politics, where one of the members of the Village Consultative Body (BPD) Desa Tempur was a Christian woman. The villagers selected her. That is, religion is not a barrier to a person's political rights. Similarly, the head of the Neighborhood Association (RT) in the Pekosa hamlet is a Christian, Suwadi, who is also a Christian leader in Tempur.

The Nurul Hikmah Mosque and the GITJ Tempur Church, which face each other and share a yard the size of a three-meter-wide street, are two concrete symbols of religious tolerance in Tempur. The church structure was built in the early 1990s. Christianity was still considered a new religion in Tempur at the time, with a small number of adherents. They can, however, build a church by donating land from one of the congregations and enlisting the help of every member of the community, both Muslims and Christians. The construction was completed as a team effort from both communities.

Meanwhile, in 2001, the Nurul Hikmah mosque was established. Residents were only given land in front of the church at the time. Following a meeting with the church community, to ensure that they could later walk side by side, a mosque was built with the help and support of all members of the community, both Christian and Muslim (Giran, 2021; Suwadi, 2021; Aly, 2021). Until now, even though there have been renovations, whether its been a church or a mosque, everyone has raised in to help. Many Muslims contributed labor and funds to the church's renovation. Similarly, many Christians facilitated in the renovation of the mosque[19]. 
The position of the church and mosque facing each other and sharing a yard in the form of a 3-meter-wide road is unique, not only in terms of the physical aspect of the building but also in its use. When there were events at the mosque where the number of participants exceeds the capacity of the mosque, such as recitation and Eid prayer, the church community will invite the congregation to use the church entrance hall. Even the church doors were opened for them. Similarly, when there was a Christmas event that invited several churches from other areas, the mosque management invited them to use the mosque's lawn to be occupied.

The mutually revitalizing relationship between Christians and Muslims is manifested not only in religious rituals, but also in daily life, both religious and non-religious. When there is a Christmas celebration, for example, many Muslim women assist and prepare for consumption. Similarly, when there is activity at the mosque, church women prepare for consumption. Christians receive shadaqah and sacrificial meat whenever there is shadaqah distribution and distribution of sacrificial meat; however, at Christmas, the church also distributes gifts to the local people. Even before Christmas, many Muslim residents provided basic food assistance to church administrators [19].

When someone is sick or dies and family in mourning, both Christians and Muslims come to pray or to help. Similarly, when natural disasters occur, such as the landslides and floods that have occurred several times in the Tempur area, there is a lot of basic food assistance provided to both Muslims and Christians. Other social activities carried out by Muslims, such as donations to the poor and orphans during the month of Muharram, are also supported by Christians, as is providing food to break the fast during the month of Ramadan [20].

\section{Overview of Pro-Existence Relationship in Giling Village}

Giling Village is a village in Pati Regency, Central Java's Gunung Wungkal sub-district. When Regent Pati Hariyanto inaugurated this village as a Village of Religious Harmony in September 2019, the Forum for Inter-Religious Harmony (FKUB) in Pati District designated it as a Village of Religious Harmony Awareness Award [21]. This village, located on the slopes of Mount Muria, is unique in that, despite its remote location, the religious composition of the inhabitants is very diverse, comprised of Islam, Buddhism, and Christianity. The diversity of religions practiced by the people of Giling Village is what contributes to the community's unique interfaith relations, which can be seen in various social activities that involve the general public regardless of their religious background.

Geographically, this village is bordered on the north by Ngablak Village, Cluwak District, to the south by Gulan Pongge Village, to the east by Bancak Village, and to the west by Jrahi Village. Giling has a population of approximately 1172 residents. It is not surprising, given its location on the slopes of Mount Muria, that the majority of the population works as farmers. Rural life has formed a unique portrait of the dialogue of life between religious communities that has been preserved over the years due to the composition of people with different religious backgrounds. Inter-religious tolerance is no longer limited to formal dialogue, but is practiced by the community in response to the dynamic's development of problems in society, one of which is the existence of harmonious neighbors between religious communities, including Christianity, Buddhism, and Islam.

So that the institutions in this village unite among their members in developing the potentiality of the village, for example: the existence of community organizations such as village structures, Nahdhatul Ulama (NU), Empowerment of Family Welfare (PKK), Karang Taruna, which synergize with each other and work together in advancing and uniting differences between religious communities [22]. This is clearly apparent from the representations of all religious elements in the village apparatus. Even during the previous 
period, the chairman of the Village Consultative Body (BPD) of Giling village was from Christian adherent member, signifying that the community and village government no longer differentiated between who and from what religion served in the village government. [23] [22].

This multi-religious village has four places of worship, one church, 23 mosques, and a mushalla. Several educational facilities and public facilities can also be said to be quite complete; at least in this village, there are 10 educational institutions, both private and public, consisting of Play Group (PAUD, TK / KB), Elementary School (SD), Qur'an Educational Institution (TPQ), and Islamic boarding schools. In practice, public schools in this village also facilitate the fulfillment of religious education needs based on the religions held by their students by providing teachers who teach specific religious lessons, even if there is only one student.

Mutual cooperation between religious believers demonstrates the inter-religious relationship that animates each other in Giling Village. People of other religions, for example, will assist in the celebration of religious holidays in one religion, so that any religious holiday automatically becomes a shared holiday for the local community. 'Like yesterday at the Vihara when there was a parking attendant event from NU Banser friends,' [22], Christian families conveyed how the tradition of Christmas celebrations also involves all religious leaders attending the holiday celebrations this Christmas [24] [25].

Not only in the context of religious holidays, but also in the context of building houses of worship, cleaning houses of worship, and repairing houses of worship in this village, villagers engage in mutual cooperation. In an interview with Mr. Suparjan [24], he described a church that had stood in Giling village since the 1970s. continue to facilitate the establishment of the church in Giling village. The church building was once damaged, but the local community worked together to repair it.

This spirit of mutual cooperation strengthens local resilience and the ability to mitigate potential conflicts. When youths of different religions once had clash, this feud has the potential to lead to conflict between youth in this village, because it involves youth from different religious backgrounds. Then, immediately, community and religious leaders intervened to reduce the likelihood of this local conflict spiraling out of control into a communal conflict. This incident did not necessarily alienate religious figures, because it was, they who were attempting to reconcile all parties involved in order to foster mutual understanding rather than turning it into a larger conflict [26].

\subsection{Humanist Theological Values in Tempur and Giling Village}

Both Muslims and Christians stated that their religious beliefs (theology) inspired a mutual tolerance attitude in the Tempur and Giling villages. Ali Mahfud, the secretary of Tempur Village and a five-year student at the Islamic boarding school in Jekulo Kudus, believes that there is a link between religious knowledge and tolerance.

"The shallower one's religious knowledge, the shallower one's tolerance. (Binary view) I am a Muslim, so other than Muslim will going to hell, that is only a hasty understanding of religion. However, if he has a broad knowledge of religion, he will recognize that Muslims, Christians, and Buddhists are all eligible to enter Allah's heaven. Because only Allah who decides who enters heaven, -and- not us [18]."

That is why, according to him, people of Nahdhatul Ulama communities are people have a high level of tolerance or, at the very least, are not rigid or fanatical enough to isolate themselves from other religious communities. Meanwhile, Christians believe that a pro-life 
attitude is a form of lived faith. As a result, he agrees that religiously passionate people have high humanely attitude.

"Diligent (religious) people will undoubtedly act humanely Those who aren't diligent are the most dangerous. Those with many nonsenses and a penchant for sneering are not diligent [19]." Petra and Ahong from the church youth in Tempur expressed a similar sentiment, stating that there was a link between diversity and tolerance. "Because religion teaches goodness, religious people should be tolerant." If religion teaches people to be intolerant, they are being taught incorrectly [27].

In Giling Village, a humane view of religion is also the basis for a pro-existence culture. This is based on an interview with Pak Suyono, a religious figure in the Giling village [26].

"In my view, we see all humans as humans, even though we are of different religions; we are all human beings, and we must respect and appreciate one another, and don't think they (other religions' followers) are in the dark, because there's a chance, they'll become Muslims like us" The local head of the village also stressed this point, describing how the people of Giling village were religious but not fanatics. "Yes, it's Islam here, but they're not fanatics." Sutrimo [22].

According to the interviews conducted in the villages of Tempur and Giling, there were many religious pillars that were lived out, both among Muslims and Christians, and that expressed themselves in a vibrant pro-existence attitude. The principle of "no obligation in accepting faith" (Quranic verse, Surah Al Baqarah: 256) becomes the philosophical basis for Muslims, allowing space for established religious differences. This can be seen in the societies of Tempur and Giling, where religious conversion and the presence of family members of various faiths are not questioned.

The presence of Christians in Tempur, for example, has been due to religious conversion since the beginning. Pak Suwadi, one of the Christian leaders, was born into a Muslim family with a dedicate Islamic heritage. His family was shaken when he became a Christian. His older brother, Giran, who is currently in charge of the Tempur mosque, disagrees with his younger brother's decision. After ten reminders and Suwadi's refusal to change his mind, Giran decided to embrace his younger brother's decision. "Well, then, it's up to you; the case's sins are carried by each person," says the narrator [28].

In Giling Village, it's the same way. When members of a family converted to different religion, they are not necessarily treated with disrespect in the society. "There was a Buddhist family yesterday, and then his son converted to Islam. He said, he converted to Islam because of God guidance, not compulsion" [26]. This phenomenon occurs in one family with various faiths, causing different religious practices in a multi-religious family. For example, consider a family whose wife teaches at the Vihara, while her husband attends the mosque, despite the fact that their children both attend the TPQ madrasah and religious school, at the same time their children also attending the Vihara in every Sunday.

The teaching of love is the fundamental foundation that is lived out in a pro-existence life from a Christian perspective. "In my faith, there is a teaching to love one another," Kristiani, a Christian in Giling, said, "so if you practice and spread love, tolerance will shape itself in society, even though we are a minority, we must love each other." [29]. Mutual help without prejudice is how love manifests itself. As a result, believers should love and be open to others. "If a secretive Christian does not want to connect with Muslims, it means he has no faith," Suwadi, a Christian leader in Tempur, said. "Why is it that Christianity, which is based on love, is not good for other people? Faithful people are not fanatics" [19].

The spirituality of giving in, is one of the features of spirituality that are illustrated in the Anabaptis-Mennonite tradition as a concrete and tangible expression of Christian love in the 
context of living together within the presence of people of other faiths [30, 31]. Poniyah, who became a Christian for the first time at Tempur, exemplified this desire to give in. Her husband was treated her badly and she wasn't agreeing with her being a Christian. She was also accused of being the source of illness and was treated sarcastically by some of her neighbors. To remain afloat in this situation, the desire to give in becomes a kind of piety, while also praying and doing good before the bond with relatives and neighbors improves [32]. Poniyah says that she always prays every night for the people of Tempur to live in peace and harmony. Christians in Giling also do the same thing, being caring, respectful, and compassionate as a call of faith in a pluralistic society [25].

The desire to yield is a substantive form of hospitality in the sense of interfaith interactions allowing respectful and mutually revitalizing interfaith connections to occur [33]. There is a desire to step back and allow others to take their place. For eg, in the Islamic community of Tempur, the mosque takmir has a strategy of turning off the top speakers of the mosque during Jumah prayer congregation and only using the lower speakers to safeguard each other. What is the reason for this? Because it could be possible that when the khotibs read the text without any filters, they could come across the term kafir, which, if misunderstood, might cause harm to non-Muslims [18].

On the other hand, Church religious ceremony and all church services will be delayed if there is overlap with Muslim prayer time. Similarly, when it comes to community celebration. Muslims will be asked to slaughter animals which will be cooked and served for the celebration, so that Muslims community can -without a doubt- enjoy the meal and not hesitate to enjoy the food served. The same thing occurred in Giling's Christian culture [26]. People prefer to refrain to themselves in order to preserve friendships with people of other faiths. "In Islam, it is not lawful to raise dogs; as a non-Muslim, I do not raise dogs to honor them, so that my friends are comfortable to play at my home" [29].

Costly tolerance, which is a manifestation of pro-existence inter-religious interactions, is manifested by the desire to make available space for others. In Tempur village provided a fascinating example, namely, in an attempt to preserve the friendly ties that have been established, the sense of reverence and fairness to citizens of other faiths is often expressed in studies at mosques and prayer rooms (mushalla). One example, once, in a meeting to discuss the preparations for the month of Ramadan at the Baitussalam Mosque, a member of a family in the village of Tempur who practices "Wahhabi Islam" shares his view, followed by arguments about bid'ah (every bid'ah is heretical and everyone who goes astray in hell). Before his rigid religious beliefs had a far-reaching effect on society, a nearby kyai intervened [18]. Here, the kyai's efforts are geared towards preserving the friendly religious traditions that have been manifested in community so far.

Pro-existence ties between religious believers address more than just social issues; they also allow each religious group to gain a greater understanding of the other. Each religious group can learn from and appreciate one another without fear of losing their religious identity. As a result, people are more able to comprehend the values of other faiths, which serves as social capital in maintaining religious tolerance.

"In Buddhism, the teachings of caring for fellow living beings, the teachings of eliminating lust and meditating (Tanha), so that mosquitoes that stick to their bodies cannot be killed, Buddhist people are often not allowed to slaughter animals and usually tell me to slaughter animal for them so that they can be enjoyed by community at large,"

a Muslim resident said in an excerpt from an interview at Giling [26]. This viewpoint was voiced by young Christians in this village during a conversation between youths who were taking turns protecting the "jogo tonggo" post. If Christians love each other, Buddhists 
love others, and Muslims believe that "Allah loves us, and we must love His creatures," I would infer that harmony will be built according to their respective viewpoints [29].

\subsection{Local Culture and Humanist Religious Construction in Tempur and Giling Village}

The Tempur and Giling people's cultural beliefs are intrinsically tied to their appreciation of religion, which manifests itself in a pro-existence attitude. Culture, according to Koentjaraningrat, comes in at least three forms: First, it manifests itself as a fluid unification of concepts, beliefs, norms, and laws, among other things. Second, culture is a diverse pattern of individual and group action. Third, which can be used as visible human-made objects. [34]. All these three forms of culture, were part of a long conversation that influences people's lives, with the belief structure and religious rites being one of the most important factors in the development of social identity and customs.

In fact, the societal local culture tends to evolve with religious elements, eroding the line of demarcation between the social structure and the local culture. In case of the people of Giling Village and Tempur Village, the assimilation process is what becomes the social capital in the establishment of tolerance relations among religious groups as well as interreligious relation. In terms of cultural history, Tempur has long been associated with Javanese culture and spirituality. Candi Angin, Candi Soka, and Candi Bubrah are three temples in the Tempur Village district. According to research conducted by the Yogyakarta Archeology Center in June and July 2019, the temples were most likely constructed during the late Majapahit period, during the 8th and 9th centuries AD [35]. This indicates that there was a large Hindu-Buddhist culture in Tempur and the Muria slopes in general.

This information is useful for exploring the origins of beliefs and faith that shape the village of Tempur's distinctive religious characteristics and attitudes. For a long time, Tempur culture has been united by these inclusive and harmonious cultural traditions. This can be seen in the tolerant life and tradition that flourished in Tempur prior to the arrival of religious plurality. This can also be traced back to the popular's belief in Candi Angin's life. Whereas in Tempur, from the outset, no one was too rich or poor, let alone in need, because the five pandawa in Candi Angin defended the village. Pandawa Lima's presence ensures that the village is still peaceful and calm. For instance, although there riots everywhere, and the citizens of Tempur Village were not instantly provoked, according to Pendawa Lima's character, who never causes havoc and lives in collective cooperation (together). Deliberation has been practiced from the beginning, even during the struggle, when young people often gathered and held discussions at Candi Angin, this tradition is still preserved, until the village administration totally structured and continues today [36].

Interreligious ties in the village of Tempur highly influenced by these cultural principles. When Christianity was first introduced to Tempur village in 1985 through Ibu Poniyah, the presence of the Tempur village population, which at the time was religiously and culturally homogeneous, was likely to cause discontent and shock. It did take place. According to Suwadi and Giran's comments, when the meetings were held, among the elders, village and religious leaders, ultimately, they claimed that the presence of a new religion (Christianity) would not be a problem in the village of Tempur, and that the society would remain harmonious and peaceful. [28, 19].

Meanwhile, in the village of Giling, local traditions and practices that have been transmitted down through generations have an impact on the pro-existence relations among religious groups, particularly among youth. The principles of shared friendship were one of them, and they are preserved and down from generation to generation in the Giling village community. The sense of togetherness in upholding social unity is the principle of the local 
value of sengkuyung mangayu bagyo. Mutual solidarity no longer asks about religious affiliation, but if a citizen has a need, neighbors would be able to forego going to work to offer assistance. As one Christian religious figure, Mr. Suparjan [24], explained, "usually during Christmas celebration, the people who guard the security section were Buddhist and Muslims, it can take the form of guarding the parking lot or distributing snacks / food, we even invite religious leaders during Christmas celebration and they commonly attending the invitation".

Apart from that, there is a ritual known as 'ater-ater,' which translates to 'deliver,' which is a custom in which those who observe religious holidays will deliver besek / berkat to their neighbors as a form of appreciation for the big day. This has become a tradition at all religious celebrations in Giling village, and both Muslim and Buddhism, as well as Christianity, see this as a way to reinforce divine brotherhood. If one of family member passed away, the ritual of kenduri / kenduren is generally carried out. In this tradition, the grieving family usually keeps a tahlilan tradition, which is usually held every day for a week after the family member passed away, then the 40-day mourning remembrance, and finally the 100-day to 1000-day mourning remembrance. In fact, this ritual is observed not only by Muslims, but also by people of other faiths, who do not participate in the reciting tahlil, but then who understand how this tradition can be viewed as social unity with a family member.

In the form of the villages of Tempur and Giling, in the course of social contact framed in different local customs, languages, cultural ritual, togetherness, shared trust, deliberation, Tanha, and sympathy become the convergence of the egos of religious groups to conquer each other. This situation is simply an image of universal understanding since it does not explicitly integrate the model of dialogue among religions. "Mutual love, mutual concern, and mutual respect," says the narrator [25].

\subsection{Transmission of Pro-Existence Values to the Next Generation}

The residents of Tempur and Giling Villages have developed their own process for passing on pro-existence religious beliefs to the next generation. This is especially critical in the face of cultural and demographic shifts that can be both a challenge and a danger to society's long-standing pro-existence relationship. In Tempur and Giling Villages, there are many channels for passing on pro-existence principles and traditions, including:

Transmission occurs as a result of common life experiences. The experience of interacting with people of other faiths and living up to society's pro-existence principles had found to be an important method of generational transmission. Young people in both Tempur and Giling villages have lived side by side since they were little, so they are not unfamiliar with people of other faiths. Mutual cooperation, for example, has become a tradition passed down from generation to generation in both Tempur and Giling villages, and has become a tale passed down to the younger generation of this village culture. Community elders, religious leaders, and local village authorities have passed along a tradition of shared cooperation, such as aiding in the building of places of worship and assisting in the renovation of houses of worship. Community awareness to support each other regardless of religious affiliation has transformed into an interesting example of how diversity is not limited an utter expression.

Young people have paid more attention to this orientation toward religious praxis, as well as their understanding of faith. The subject of religious identity is seen as a private matter that does not need attention. The fruit of religious life, as expressed by Pariyono, is the most important thing to highlight "In Indonesian social life, the name of religion does not need to be highlighted, oh, this is where I am correct, this is where I am incorrect. The output is the most essential aspect. It's just in perspective, whether you're A or B, red or white." Petra and 
Ahong, as Christian youths in Tempur, shared the same message: religion should also have meaningful ideals for mankind because religion teaches what is good. It is not necessary to stress one's own values when teaching faith. "All we do is teach through our behavior [27]." They admit that their parents have told them since childhood that they should not need to discredit others when associating with others.

Transmission is often achieved through the organization, in addition to experience. In Tempur village, one point interesting to note is the presence of youth organisations in each dukuh [27]. This youth group focuses its activities on assisting the community, especially through community service, and does not address religious matters. Indeed, different topics relating to religious issues that are currently trending on social media are sometimes casually discussed, but these issues are discussed from the viewpoint of tolerance culture which has been preserved in the village.

For example, they differ on different topics concerning bigotry and intolerance which was done by certain religious organization. It may be argued that cultural praxis, rather than religious discussions, is the primary priority of youth groups. Meanwhile, the PKK is the organization that is responsible for cultural transmission in Giling. Mrs. Jemiati, a local RT woman, is often asked to provide material for cooking demo at RT routine meetings, since the PKK routine association among mothers has become a meeting room and a place of crossreligious interaction. The PKK monthly association's culture has been retained and passed on from generation to generation as an example of how life's discourse is developed and sustained as part of a habit that is passed down from generation to generation

\section{Conclusion}

Motivation and manifestation of cultural expressions show the connection between religion and society. Religion is the basic manner in which humans perceive and understand the environment. If culture expresses how humans experience and understand the world, religion demonstrates how humans experience and understand the world. As a result, religion will have an effect on more than just people's behaviors. Since religious traditions form and are influenced by the surrounding society, they may have a significant impact on an entire population, country, or territory. So that religion will play a significant part in promoting peace and social cohesion.

The portrait of a humanist religious depiction in the context of Tempur, Jepara and Giling villages, Pati will provide an outline of the life story of pro-existence religious interactions, some points that can be the findings of this research, among others: First, the spiritual component of faith, or religious belief values - The living religion becomes the foundation for how interreligious relationships that animate each other can be established, sustained, and addressed, so that these religious beliefs can be understood explicitly by other religions.

Second; The local culture and traditions that have been practiced from generation to generation by the community have become a space for interreligious dialogue, so that in practice, religious expression which is based on the theological foundation of religion has transformed into a social system that is contextualized with the traditions that have been practiced by the local community. Third, the constant repetition of the tradition has strengthened the pillar of social stability, making it a buffer against potential conflicts, and 
these ties build community resilience to potential conflicts, as well as a mechanism of passing values down to the next generation.

Ultimately, the emphasis and intent of this study, which is to focus more on the humanist appreciation of faith, which allows multi-religious cultures to live tolerantly and restore one another, has limits. There are also other topics that should be studied further. Assessing how political, social, and economic conditions contribute to foster tolerant attitudes in the two villages, for example. Aside from that, it will be beneficial to look at how cultural shifts and more intense social experiences influence the patterns of tolerance in the two villages.

\section{References}

[1] SETARA Institute, "SETARA Institute," 29 September 2020. [Online]. Available: https://setarainstitute.org/terjadi-penjalaran-intoleransi-di-daerah-pemerintah-pusat-harus-hadir/. [Diakses 13 Januari 2021].

[2] M. v. Bruinessen, Contemporary Develpoment in Indonesian Islam, Singapore: ISEAS Publishing, 2018, pp. 1-20.

[3] L. Koffeman, "Costly Tolerance," HTS Teologiese Studies/Theological Studies 72(1), a3282, http://dx.doi. org/10.4102/hts.v72i1.3282, p. 6, 2016.

[4] Suhadi, "Costly Tolerance: Tantangan Dialog di Indonesia dan Belanda," in Costly Tolerance, Tantangan Baru Dialog Muslim Kristen di Indonesia dan Belanda, Suhadi, Ed., Yogyakarta, CRCS (Center for Religious and Cross-cultural Studies) UGM, 2018, pp. 1-13.

[5] S. A. Qurtuby, "Reconciliation from Below: Indonesia's Religious Conflict and Grassroots Agency for Peace," Peace Research: The Canadian Journal of Peace and Conflict Studies, pp. 152-153, 2012/2013.

[6] C. Pasandaran, "Central Java Village Shows That Unity in Diversity Is Possible," http://jakartaglobe.id/news/central-java-village-shows-that-unity-in-diversity-is-possible/, 2014.

[7] A. E. Galeotti, Toleration as Recognition, Cambridge: Cambridge UP, 2004.

[8] C. Taylor, "The Politic of Recognition," in Multiculturalism, Princenton, Princeton UP, 1994, p. 25.

[9] Sri Wismoady Wahono and Armando Riyanto, "Agama: Dari Isolasi ke Pro-Eksistensi," Jurnal Toleransi, p. 4, 2002.

[10] M. Rosyid, "Harmoni dab Kehidupan Sosial Beda Agama dan Aliran di Kudus," Addin, pp. 41-64, 2013.

[11] C. Sirodz, Kerukunan Tiga Agama Relasi Islam, Budha, dan Kristen dalam Terciptanya Keragaman Di Desa Jrahi Kec. Gunungwungkal Kab. Pati, Yogyakarta: Skripsi UIN Sunan Kalijaga, 2020.

[12] S. Ma'arif, "Strategi Komunikasi Antar Umat Beragama dalam Menumbuhkan Ukhuwwah Wathaniyyah di Desa Plajan Kecamatan Pakis Aji Kabupaten Jepara," An-Nida, pp. 143-160, 2015.

[13] M. A. Mushodiq, "Teori Identitas dalam Pluralisme dan Toleransi Beragama: Studi di Desa Jrahi, Gunungwungkal, Pati, Jawa Tengah,” Fikri, pp. 279-406, 2017.

[14] Ahmad Saefudin and Fathur Rohman, "Teologi Damai Agama Islam, Hindu, dan Kristen di Plajan Pakis Aji Jepara," Al-Qalam, pp. 393-403, 2019.

[15] M. B. McGuire, Lived Religion: Faith and Practice in Everyday Life, New York: Oxford, 2008.

[16] N. T. Ammerman, Everyday Religion, New York: Oxford, 2007.

[17] Srfjan Sremac and R. Ruard Ganzevoort, "Lived Religion and Lived (in) Tolerance," dalam Lived Religion and the Politics of (In) Tolerance, Cham, Palgrave-MacMillan, 2017, p. 17.

[18] A. Mahfud, Interviewee, Wawancara. [Wawancara]. 31 Januari 2021.

[19] Suwadi, Interviewee, Interview. [Wawancara]. 31 Januari 2021.

[20] Supami, Interviewee, Wawancara. [Wawancara]. 31 Januari 2021.

[21] Pemerintah Kabupaten Pati, "Pemerintah Kabupaten Pati," 9 September 2019. [Online]. Available: https://www.patikab.go.id/v2/id/2019/09/07/miliki-kades-minoritas-giling-justru-dicanangkan-j/. [Diakses 24 Pebruari 2021].

[22] Sutrimo, Interviewee, Kepala Desa Giling. [Wawancara]. 14 Pebruari 2021. 
[23] B. Rustanto, Interviewee, Warga dan Tokoh Agama Islam. [Wawancara]. 14 Pebruari 2021.

[24] Suparjan, Interviewee, Tokoh Agama Kristen Desa Giling. [Wawancara]. 14 Pebruari 2021.

[25] Jemiati, Interviewee, Ibu RT Desa Giling. [Wawancara]. 14 Pebruari 2020.

[26] Suyono, Interviewee, Kesra desa dan Tokoh Agama Islam. [Wawancara]. 14 Februari 2021.

[27] P. d. Ahong, Interviewee, Wawancara. [Wawancara]. 31 Januari 2021.

[28] Giran, Interviewee, Wawancara. [Wawancara]. 31 Januari 2021.

[29] H. Kristiani, Interviewee, Mahasiswa Penganut Kristen. [Wawancara]. 14 Februari 2021.

[30] C. J. Dyck, Spiritual Life in Anabaptism, Scottdale: Herald Press, 1995.

[31] J. Driver, Life Together in the Spirit: A Radical Spirituality for the Twenty-First Century, Mennonite World Conference, 2015.

[32] Poniyah, Interviewee, Wawancara. [Wawancara]. 31 Januari 2021.

[33] S. A. A. Aihiokhai, Fostering Interreligious Encounters in Pluralist Societies: Hospitality and Friendship, Portland: Palgrave Macmillan, 2019.

[34] Koentjaraningrat, Kebudayaan Mentalitas dan Pembangunan, Jakarta: Gramedia Pustaka Utama, 2015, pp. 6-10.

[35] Murianews.com, 2019. [Online]. Available: https://www.murianews.com/2019/06/26/167011/usiacandi-angin-di-gunung-muria-dilacak-ahli-dari-balar.html.

[36] [Online]. Available: https://keling.jepara.go.id/kelurahan-desa-tempur/.

[37] L. Swidler, "What Is Dialogue," [Online]. Available: https://dialogueinstitute.org/what-is-dialogue.

[38] L. Swidler, Dialogue for Interreligious Understanding: Strategies for the Transformation of CultureShaping Institutions, New York: Palgrave MacMillan, 2014.

[39] M. T. Thangaraj, The Common Task: A Theology of Christian Mission, Nashville: Abingdon Press, 1999.

[40] Kasiran, Interviewee, Mantan Kepala Desa Giling. [Wawancara]. 22 Januari 2020.

[41] B. Keling, "Kecamatan Keling Dalam Angka 2019," Badan Pusat Statistik Kabupaten Jepara, Jepara, 2020.

[42] A. Pariyono, Interviewee, Wawancara. [Wawancara]. 31 Januari 2021.

[43] L. Swidler, Dialogue for Interreligious Understanding, Macmillan: Palgrave, 2014.

[44] J.B. Banawiratma, Zainal A. Bagir (ed), Dialog Antarumat Beragama Gagasan dan PRaktik di Indonesia, Jakarta: Mizan Publika, 2010. 